\title{
Pertanggungjawaban Pidana Korporasi Dalam Tindak Pidana Narkotika
}

\author{
Andrika Imanuel Tarigan \\ Program Studi Magister Hukum Universitas Indonesia \\ andrikatarigan2@gmail.com
}

\begin{abstract}
Abstrak. Tindak Pidana Narkotika merupakan suatu hal yang sangat luar biasa yang dapat merusak dan mental dan fisik dalam kehidupan bermasyarakat, berpotensi menghambat tindak perekonomian suatu negara. Tindak pidana narkotika ini dilakukan bukan saja oleh orang perorangan melainkan pada perkembangannya bisa oleh korporasi. Korporasi juga dapat melakuakan tindak pidana pencucian uang. Kejahatan dalam tindak pidana pencucian uang yang dilakukan oleh sebuah korporasi bukan sautu hal yang mudah untuk dilakukan penanggulangan, diusut bahkan untuk dijerat. Dalam peraturan perundang-undangan yang berlaku di Indonesia untuk menjadikan korporasi sebagai suatu subjek tindak pidana dalam proses penegakkan hukumnya masih sangat lambat. Berkembanganya kejahatan yang dilakukan oleh korporasi sebagai suatu subjek tindak pidana, maka diperlukan adanya pandangan yang baru tentang pertanggungjawaban pidana korporasi yang melakukan tindak pidana, khususnya dalam penanggulangan dan penegakan tindak pidana Pencucian Uang dengan tindak pidana asal dari tindak pidana narkotika.
\end{abstract}

Kata Kunci: Korporasi, Narkotika, Tindak Pidana Pencucian uang.

Abstract. Narcotics Crime is a very extraordinary thing that can damage and mentally and physically in social life, has the potential to hinder the economic action of a country. Narcotics crime is committed not only by individuals but also by corporations. Corporations can also commit money laundering crimes. Crime in the crime of money laundering committed by a corporation is not an easy thing to do to overcome, to investigate and even to be charged. In the laws and regulations in force in Indonesia, to make corporations a subject of criminal acts, the law enforcement process is still very slow. With the development of crimes committed by corporations as a subject of criminal acts, it is necessary to have a new perspective on the criminal responsibility of corporations that commit criminal acts, especially in the prevention and enforcement of the crime of money laundering with the original crime of narcotics crime.

Keywords: Corporations, Narcotics, Money Laundering Crime.

\section{PENDAHULUAN}

Salah satu yang menjadi perhatian penting dalam penegakaan hukum pidana di Indonesia saat ini adalah penanggulangan kejahatana tindak pidana Narkotika. Pada masyarakat Indonesia maupun masyarakat di dunia saat ini dihadapkan pada keadaan yang mengkhawatirkan akibat semakin maraknya pemakaian secara sah berbagai jenis narkotika. Tindak Pidana Narkotika yang merupakan tindak pidana asal dalam tindak pidana pencucian uang, hal ini dilihat dari hubungan antara tindak pidana pencucian uang dengan tindak pidana asal tindak penyalahgunaan narkotika pada harta kekayaan yang berasal dari suatu tindak pidana yang telah dilakukan di wilayah Indonesia maupun dilakukan di luar wilayah Negara Kesatuan Republik Indonesia. Tindak pidana tersebut adalah merupakan tindak pidana pencucian uang apabila terdapat kejahatan yang menghasilkan uang atau harta kekayaan yang berupa hasil dari suatu tindak pidana narkotika. Dalam ketentuan peraturan perundang-undangan tentang Pencucian Uang di Indonesia tidak saja menangkap pelaku yang merupakan organized crime, penyalahguna 
narkotika akan tetapi juga guna menelusuri hasil dari kejahatan Narkotika dan untuk merampas aset para pelaku tindak pidana narkotika.

Permasalahan penegakan hukum tindak pidana pencucian uang pada tindak pidana narkotika sebagai tindak pidana asal. Bahwa yang menajdi fakta saat ini terjadi para pelaku tindak pidana narkotika mengerti bagaimana sistem finansial, bagaimana suatu bank bekerja, bentuk-bentuk investasi, sehingga memudahkan dalam melakukan atau menutupi uang dari hasil kejahatan narkotika yang sangat sulit nantinya untuk dilakukan pengungkapan. Hasil dari kejahatan narkotika yang disamarkan atau dikaburkan nampaknya seolah-olah sebagai suatu yang wajar/halal, kemudian uang hasil kejahatan itulah yang digunakan untuk membuat usaha sehingga nanti apabila terdapat pemasukkan uang dari hasil tindak pidana narkotika tidak dicurigai sebagai suatu tindak pidana pencucian uang.

Pengaturan Tindak Pidana Narkotika di Indonesia berdasarkan ketentuan UndangUndang Nomor 35 Tahun 2009 tentang Narkotika yang mengatur bagaimana tentang perbuatan yang dilarang dan diancam pidana terhadap penyalahguna, kurir maupun para Bandar. Hal Ini juga dapat dikenakan terhadap orang maupun terhadap badan hukum (korporasi). Hal ini dilihat sesuai dengan penjabaran Pasal 130 Undang-Undang Narkotika maka dapat disimpulkan pembebanan pertanggungjawaban pidana ditujukan kepada orang/korporasi, maka dapat dilihat 4 bentuk pertanggungjawaban pidana korporasi, yaitu sebagai berikut pertanggungjawaban pidana mutlak, pertanggungjawaban pidana pengganti, pertanggungjawaban identifikasi, dan pertanggungjawaban pidana agregasi yang merupakan bagian dari pertanggungjawban pidana berdasarkan kesalahan (liability base on fault) atau yang pada prinsipnya menganut suatu asas kesalahan atau asas culpabilitas. Berdasarkan penjelasan diatas, penulis tertarik untuk menulis artikel berjudul "Pertanggungjawaban Pidana Korporasi Dalam
Tindak Pidana Narkotika Sebagai Tindak Pidana Asal Dalam Tindak Pidana Pencucian Uang".

\section{METODE PENELITIAN}

Data yang telah dikumpulkan akan dianalisis berdasarkan metode kualitatif yaitu untuk mendapatkan gambaran secara deskrpitif - analitis yaitu yang merupakan penelitian yang dilakukan secara tertulis atau lisan sesuai dengan perilaku nyata. Sementara hasil analisa akan disajikan dalam bentuk deskriptif - analitis, yakni yang menggambarkan suatu peraturan perundang-undangan yang dikaitkan dengan teori-teori hukum dan dengan praktek pelaksanaan hukum terkait dengan Pertanggungjawaban Pidana Korporasi Dalam Tindak Pidana Narkotika Sebagai Tindak Pidana Asal Dalam Tindak Pidana Pencucian Uang. Deskriptif yaitu adalah suatu penelitian yang dilakukan dengan tujuan untuk mentis terhdapa fokus penelitian, dan juga melakukan analitis terhdap data-data yang diperoleh.

Tipe dalam penulisan artikel ini merupakan deskriptif - preskriptif, Penelitian deskriptif dilakukan untuk mendapatkan gamabaran yang menyeluruh dan juga sistem yang menggambarkan keadaan, sifat individu, gejala/kelompok tertentu, menentukan penyebaraan suatu gejala atau menentukan melihat terdapat atau tidak hubungan antara suatu gejala dengan gejala yang lain dalam suatu masyarakat. Penelitian yang perspektif adalah suatu penelitian yang mempunyai tujuan untuk memberikan gambaran atau merumuskan tentang masalah yang sesuai dengan keadaan atau fakta yang ada.

\section{A. HASIL DAN PEMBAHASAN}

\section{TINDAK PIDANA NAKOTIKA}

Pengertian dari Narkotika dari berasal dari bahasa Yunani yaitu "narke" atau "narkum" yang adalah mempunyai arti tidak dapat merasakan apa-apa atau terbius. dikenal dengan sebutan "narcose" berarti menidurkan atau melakukan pembiusan dalam bahasa Inggris, sebagian juga menyebutnya dengan istilah "narcotic" yang mempunyai arti adalah sesuatu yang dapat menghilangkan rasa nyeri 
Jurnal Ilmiah Mandala Education

http://ejournal.mandalanursa.org/index.php/JIME/index

Terakreditasi Peringkat 4 (No. SK: 36/E/KPT/2019) dan dapat menimbulkan efek (bengong), bahanbahan pembius dan obat-obat pembius UndangUndang Nomor 35 Tahun 2009 tentang Narkotika mempunyai tujuan yaitu mencegah terjadinya penyalahgunaan narkotika dan memberantas peredaran gelap narkotika. Keduanya yang saling berkaitan satu dengan yang lain, yaitu mencegah terjadinya penyalahgunaan narkotika merupakan tindakan menutup pintu bagi "konsumen narkotika yang tidak sah sehingga arus peredaran gelap narkotika terputus dan tidak sampai beredar ke tingkat yang paling bawah, dengan memberantas peredaran gelap narkotika, maka konsumen narkotika yang tidak sah" tentu keuslitan untuk mendapatakan dan menggunakan narkotika lagi.

Tindak pidana narkotika merupakan suatu tindak pidana yang berupa: produksi, impor/ekspor, peredaran gelap narkoba, pengangkutan, penyalahgunaan narkotika, pemufakatan jahat, transito narkotika, kejahatan terorganisasi.Jenis zat atau obat dalam tindak pidana narkotika sendiri terbagi 2 jenis, yaitu yang pertama adalah Narkotika merupakan zat atau obat yang berasal dari tanaman maupun bukan tanaman, baik sintesis maupun semisintesis, yang dapat menyebabkan penurunan atau perubahan kesadaran, hilangnya rasa nyeri, dan dapat menimbulkan ketergantungan, yang dibedakan kedalam golongan-golongan. yang kedua adalah Psikotropika merupakan zat atau obat, baik alamiah maupun sintetis bukan narkotika, yag berkhasiat psikoaktif melalui pengaruh selektif pada susunan saraf pusat yang menyebabkan perubahan khas pada aktivitas mental dan perilaku, dan yang ketiga adalah Adiktif adalah bahan yang penggunaannya dapat menimbulkan ketergantungan psikis. Pemberlakuannya untuk obat dan narkotika baik yang legal maupun illegal dan secara langsung maupun secara tidak langsung.

Penyalahguna Narkotika tidak hanya dapat mengalami kerugian materi, namun juga terdapat kerugian psikis, sosial, fisik dan kesehatan. Dalam hal keugian sosial yang dialami seorang penyalahguna narkotika yaitu mendapatkan suatu stigma atau pandangan yang buruk dari masyarakat, terkadang banyak yang menyebutnya sebagai sampah masyarakat. Kerugian psikis yang diakibatkan oleh pengguna narkotika adalah masalah dengan kondisi kejiwaan yang kurang stabil karena ketergantungan dari Narkotika Kekhawatiran Pemerintah tentang akan adanya ancaman yang menyatakan bahwa narkotika bisa merusak generasi muda dalam hal ini belum disertai dengan data-data pendukung anak-anak yang terpapar oleh narkotika. Terdapat beberapa aspek perhatian utama untuk memberantas narkotika dalam Undang-Undang Nomor 35 Tahun 2009 tentang Narkotika, yaitu yang pertama adalah Aspek Penanggulangan, yang kedua Aspek Pencegahan, dan yang terakhir adalah Aspek Rehabilitasi.

Bahwa jelas Undang-Undang Nomor 35 Tahun 2009 memberikan fasilitasi dengan perubahan paradigm atau cara pandang yang dahulu berorientasi pada hukuman (punishment) atau kriminalisasi dengan dominasi dari aspek pidana sekarang bergeser menjadi aspek kemanusiaan atau yang lebih berpihak kepada korban dalam bentuk depenalisasi atau dekriminalisasi yang mengedepankan aspek rehabilitsi medis dan sosial atau sering dikenal dengan istilah rehabilitasi yang berkelanjutan. Pengertian Peredaran Gelap Narkotika adalah setiap kegiataan atau serangkaian kegiataan yang dilakukan secara tanoa hak atau kegiaatan yang ditetapkan sebagai tindak pidana narkotika.Bahwa eksistensi dari para penegak hukum terlihat membela para pelaku kejahatan dan terkesan kurang memperhatikan korban dari tindak pidana narkotika yang mempunyai efek ketergantungan. Konteks penegakan hukum di Indonesia dalam hal pemidanaan seharusnya dapat merujuk dengan pendekatan norma yaitu dengan cara menghukum para penjahat sehingga dapat memberikan efek jera. Penegakan Hukum dalam hal narkotika haruslah memiliki persepsi yang sama baik dalam tingkat penyidikan, penututan dan sampai ke tingakat peradilan sesuai dengan keadilan masyarakat. 


\section{PERTANGGgUNGJAWABAN PIDANA KORPORASI DALAM TINDAK PIDANA NARKOTIKA}

Terminologi dalam tindak pidana korporasi di Indonesia dimulai dengan munculnya beberapa Undang-Undang di luar KUHP yang bersifat khusus dan dengan tegas mengatur korporasi sebagai suatu subjek hukum dan dapat dikenakan sanksi pidana apabila melakukan tindak pidana, Berdasarkan UU Darurat No.12 Tahun 1951 tentang Senjata Api dan UU Darurat No. 17 Tahun 1951 tentang Penimbunan Barang-Barang, namun belum didefinisikan secara kongkrit mengenai korporasi. Perkembangnya korporasi memiliki peran yang semakin kuat dalam kehidupan masyarakat maka dalam perkembangan berikutnya banyak sekali perundang-undangan diluar KUHP yang menempatkan korporasi sebagai subyek hukum. Korporasi merupakan entitas atau subjek hukum yang keberadaannya memberikan kontribusi yang besar dalam meningkatkan pertumbuhan ekonomi dan pembangunan nasional, tapi dalam kenyataannya korporasi ada kalanya juga melakukan berbagai tindak pidana (corporate crime) yang membawa dampak kerugian terhadap negara dan masyarakat. Korporasi menurut Kamus Hukum Fockema Andreae yaitu suatu badan hukum yang terikat dan memiliki tujuan tertentu, yang memperlihatkan subjek hukum itu sendiri. Mengenai hakekat dari korporasi itu sendiri pada dasarnya dapat dilihat dari pernyataan klasik Viscount Haldane L.C., yang menyatakan bahwa "Korporasi adalah suatu abstraksi. Ia tidak lagi memiliki pikirannya sendiri dibanding dengan tubuhnya sendiri; kehendak yang dijalankan dan bersifat mengarahkan harus secara konsisten dilihat pada seseorang yang untuk tujuan tertentu mungkin disebut agen atau wakil, tetapi yang sebenarnya mengarahkan pikiran dan kehendak dari korporasi, yaitu ego dan pusat korporasi". Sedangkan menurut Satjipto Rahardjo dalam bukunya yang berjudul Ilmu Hukum dikemukakan bahwa yang dimaksud dengan korporasi adalah "Badan yang diciptakannya itu terdiri dari corpus, yaitu struktur fisiknya dan ke dalamnya hukum memasukkan unsur animus yang membuat badan itu mempunyai kepribadian. Oleh karena badan hukum ini merupakan ciptaan hukum, maka kecuali penciptaannya, kematiannyapun ditentukan oleh hukum".

korporasi dalam pengertian badan hukum atau pelaku fungsional dalam hukum pidana merupakan perkembangan yang sangat maju dengan menggeser doktrin yang mewarnai Wetboek van strafrecht (KUHP) yakni "universitas delinquere non potest" atau "societas delinquere non potest" yaitu badan hukum yang tidak dapat melakukan suatu tindak pidana. Korporasi bertanggungjawab kepada tindak pidana narkotika dikarenakan, perederan narkotika tidak hanya antar individu, juga dapat dilakukan oleh korporasi dengan individu yang dilakukan pleh prekursor. Dalam UndangUndang Nomor 35 Tahun 2009 tentang Narkotika, melarang dan mengancam pidana terhadap penyalahguna Narkotika, berupa orang perorangan ataupun badan hukum (korporasi), Penyalahguna Narkotika dapat berupa orang perorangan maupun badan hukum (korporasi). yang menurut Undang-Undang No. 35 Tahun 2009 tentang Narkotika, dirumuskan pada Pasal 1 Angka 13, bahwa "Pecandu Narkotika adalah orang yang menggunakan atau menyalahgunakan Narkotika dan dalam keadaan ketergantungan pada Narkotika, baik secara fisik maupun psikis.

Peredaran Narkotika merupakan suatu sel yang terputus sehingga anggota-anggota tersebut tidak saling mengenal satu dengan yang lain. Namun, para anggota dalam jaringan narkotika tetap membentuk jaringan kerja yang saling memperngaruhi dan mengamankan bisnis yang tujuan nya untuk menghasilkan keuntungan yang sebesar-besarnya. Terdapat dua jenis transaksi dalam perdagangan narkotika, pertama yang dilakukan secara terbuka yakni yang merupkan daerah yang dikuasia oleh para preman dan pada daerah yang tingkat rawan kejahatan nya adalah sangat luarbiasa atau tinggi. Kedua, adalah yang 
dilakukan secara tertutup di Indonesia relatif penegakan hukum terjadi pada model transaksi yang kedua. Berdasarkan penjabaran diatas, maka dapat disimpulkan bahwa perdagangan narkotika dapat dijalankan secara berorganisasi ataupun perorangan, seperti yang dijabarkan dalam pasal 130 dan Pasal 137 Undang-Undang Narkotika maka dapat disimpulkan pembebanan pertanggungjawaban pidana ditujukan kepada orang/korporasi maka dapat dilihat 4 (empat) bentuk pertanggungjawaban pidana korporasi, yakni pertanggungjawaban pidana pengganti, pertanggungjawaban pidana mutlak, pertanggungjawaban identifikasi, dan pertanggungjawaban pidana agregasi yang merupakan bagian dari pertanggungjawaban pidana yang sesuai dengan kesalahan (liability base on fault) atau yang menganut asas kesalahan atau asas culpabilitas.

Pertanggungjawaban pengganti atau yang biasa dikenal dengan istilah (vicarious liability atau respondent superior) adalah sebagai salah satu dari bentuk pertanggungjawaban korporasi yang paling banyak diterapkan di berbagai negara. Pertanggungjawaban ini, korporasi bertanggungjawab atas tindak pidana yang dilakukan oleh pegawai atau karyawannya, tanpa melihat status/kedudukan orang tersebut di dalam korporasi. Bahwa yang menjadi catatan adalah bahwa pertanggungjawaban pengganti ini dapat dikenakan kepada korporasi (corporate vicarious liability), ataupun kepada pemimpin/ pengurus korporasi (individual vicarious liability). Kemudian, teori petanggungjawaban identifikasi, dalam hal ini pembebanan pertanggungjawaban pidana dibebankan kepada korporasi bertanggungjawab dalam suatu tindak pidana yang dilakukan oleh pengurus/ pemimpin korporasi. Dalam teori Agregasi dimungkinkan suatu kombinasi dalam sauatu perbuatan atau actus reus dan kesalahan atau mens rea dari sejumlah orang sejumlah orang, untuk diatributkan kepada korporasi, sehingga pertanggungjawaban pidana dapat dibebankan kepada badan hukum jika perbuatan tersebut dilakukan oleh sejumlah orang yang memenuhi unsur delik yang mana antara satu dengan yang lain saling terkait dan bukan berdiri sendirisendiri. Dalam hal ini, maka pertanggungjawaban korporasi bukanlah merupakan turunan dari tindak pidana seseorang, tetapi merupakan hasil dari kesalahan korporasi itu sendiri.

Penerapan asas pertanggungjawaban pidana mutlak didalam Pasal 111, 112 ayat (1), 117 ayat (1), dan pasal 122 ayat (1) UU Narkotika diterapkan bilamana orang dalam perbuatannya sudah memenuhi unsur pasal maka orang tersebut sudah melakukan tindak pidana narkotika. Serta kejahatan narkotika ini termasuk kedalam kejahatan transnasional Organized Crime yang persebarannya begitu cepat dan tanpa mengenal batas wilayah dengan melihat hal tersebut maka dari itu keberlakukan asas strict liability diberlakukan didalam UU Narkotika tentunya dalam hal pencegahan dan pemberantasan tindak pidana Narkotika. Dalam proses pembuktian kesalahan merupakan hal yang sangat penting didalam hukum pidana dimana dengan kesalahan seseorang dapat mempertanggungjawabkan perbuatannya. UU Narkotika dalam ketentuan pidananya tidak menjelaskan secara jelas unsur kesalahan namun dalam pembuktian tindak pidana narkotika dalam proses pemidanaan dalam persidangan unsur kesalahan tersebut tetap harus ada tanpa mengenyampingkan asas geen straf zonder schuld, karena pentingnya kesalahan ini dalam proses pembuktian. Kewenangan hakim disini dalam proses pembuktian sangat penting untuk membuktikan orang bersalah atau tidak.

\section{B. KESIMPULAN}

1. Tindak pidana narkotika merupakan tindak pidana yang berupa: produksi, impor/ekspor, peredaran gelap narkoba, pengangkutan, penyalahgunaan narkotika, pemufakatan jahat, transito narkotika, kejahatan terorganisasi.

2. Bentuk pertanggungjawaban korporasi pada tindak pidana narkotika dijabarkan dalam pasal 130 Undang-Undang Narkotika maka dapat disimpulkan 
pembebanan pertanggungjawaban pidana ditujukan kepada orang/korporasi, maka dapat dilihat 4 (empat) bentuk pertanggungjawaban pidana korporasi, yakni pertanggungjawaban pidana mutlak, pertanggungjawaban pidana pengganti, pertanggungjawaban identifikasi, dan pertanggungjawaban pidana agregasi yang merupakan bagian dari pertanggungjawban pidana berdasarkan kesalahan (liability base on fault) atau pada prinsipnya menganut asas kesalahan atau asas culpabilitas.

C. Rekomendasi

1. Dalam Penegakan hukum tindak pidana narkotika tidak hanya menerpakan pertanggungjawab subyek pidana hanya kepada orang perorangan saja melainkan harus juga dapat menjerat korporasi sebagai pelaku tindak pidana.

2. Perlunya peningkatan pengetahuan, pendidikan dan pelatihan khusus kepada aparat penegak hukum sehingga bersinergi dalam penanganan tindak pidana narkotika.

\section{DAFTAR PUSTAKA}

\section{Buku}

Amiruddin dan Zainal Askin, Pengantar Metode Penelitian Hukum, Jakarta: PT. Raja Grafindo Persada.

Fuady. Munir, Hukum Perbankan Modern, Bandung: Citra Aditya Bakti, 2001.

Hanitijo. Ronny, Meetode Penelitian Hukum dan Jurimateri, Jakarta: Ghalia Indonesia, 1998.

Hari Sasangka, Narkotika dan Psikotropika dalam Hukum Pidana, Bandung: CV. Mandar Maju, 2003.

Kaka Alvian Nasuition, Himpunan Lengkap Undang-Undang Narkotika dan Psikotropika, Jogjakarta: Saufa, 2014.

Lydia Harlina Marton, Membantu Pecandu Narkotika Dan Keluarga, Jakarta: Balai Pusataka, 2006.
Mardani, Penyalahgunaan Narkotika dalam Perspektif Hukum Pidana Islam dan Hukum Pidana Nasional, Jakarta: RajaGrafindo, 2005.

Marton. Lydia Harlina, Membantu Pecandu Narkotika dan keluarga, Jakarta: Balai Pustaka, 2006.

Nurbani. H. Salim HS dan Erlies Septiana, Penerapan Teori Hukum Pada Penelitian Tseis dan Desertasi, Jakarta: PT Raja Grafindo Persada, 2013.

Priyatno. Muladi dan Dwipa, Pertanggungan Korporasi dalam Hukum Pidana, STBH; 1991.

Rahardjo. Satjipto, Ilmu Hukum, Bandung: Citra Aditya Bakti, 2000.

Ronny Hanitijo, Metode Penelitian Hukum dan Jurimateri, Jakarta: Ghalia Indonesia. 1988.

Sunarsono. Siswanto, Penegakan Hukum Psikotropika Dalam Kajian Sosiologi Hukum, Jakarta: 2004, Grafindo.

\section{Jurnal}

A. Hamzah, Pemidanaan Terhadap Penyalahgunaan Prekursor Di Kalangan Korporasi, Lex Crimen Vol. III/No. 2/April/2014.

Andri G. Wibisana, Kejahatan Lingkungan Oleh Korporasi: Mencari Pertanggungjawaban Korporasi dan Pimimpin/Pengurus Korporasi Untuk Kejahatan Lingkungan Di Indonesia, Jurnal Hukum \& Pembangunan No. 46 No. 2, 2016.

Andri Winjaya Laksana, Tinjauan Hukum Pemidanaan Terhadap Pelaku Penyalahguna Narkotika Dengan Sistem Rehabilitasi, Jurnal Pembaharuan Hukum Volume II No. 1 Januari - April 2015.

Anton Sudanto, Penerapan Hukum Pidana Narkotika Di Indonesia, ADIL: Jurnal Hukum Vol. 7 No.1, hlm. 139.

Astri Heiza Mellisa, Money Laundering With Drugs Predicate Crime Study Of Court 
Decision No. 1243/Pid.B/2012/Pn.Mdn. Dated 08 October 2012, USU Law Journal, Vol 2 No. 3 Desember 2014.

Bambang Ali Kusumo, Pertanggungjawaban Korporasi Dalam Hukum Pidana di Indonesia, Wacana Hukum, Vol. VII No. 2, Oktober 2008.

Budi Suhariyanto, Pertanggungjawaban Pidana Korporasi Berdasarkan Corporate Culture Model Dan Implikasinya Bagi Kesejahteraan Masyarakat, Jurnal RechtsVinding, Vol. 6 No. 3, Desember 2017.

Chartika Junike Kiaking, Penyalahgunaan Narkotika Menurut Hukum Pidana Dan Undang-Undang Nomor 35 Tahun 2009 Tentang Narkotika, Lex Crimen Vol. VI/No. 1/Jan-Feb/2017.

Faisol, Pertanggungjawaban Pidana Pengurus Korporasi Terkait Tindak Pidana Perdagangan Orang, Yurispruden Volume 2, Nomor 2, Juni 2019.

Henry Donald Lbn Toruan, Pertanggungjawaban Pidana Korupsi Korporasi, Jurnal RechtsVInding, Vol. 3 No. 3, Desember 2014.

Joni Sastrawan Sinuraya, Pertanggungjawaban Pidana Perantara Dalam Jual Beli Narkotika (Studi Putusan No. 18/Pid.B/2012/PN.BT), Skripsi (Medan: Universitas HKBP Nommensen, 2014), hlm. 27.

Joshua Gilberth Kawinda, Pertanggungjawaban Korporasi Dalam Tindak Pidana Korupsi Di Bidang Pengadaan Barang Dan Jasa Sektor Konstruksi, Lex Privatum Vol. V/No. 6/Ags/2017.

Mardjono Reksodiputro, Mengantisipasi Pemberantasan Perdagangan Ilegal Narkotika, Jurnal Peradilan Indonesia Vol. 5, Agustus 2016 - Januari 2017.

Mompang L. Panggabean, Pertanggungjawaban Korporasi Dalam Hukum Pidana Kajian Putusan No. 1405 K/Pid.Sus/2013, Jurnal Kajian Putusan Pengadilan Dictum Edisi 12 - Maret 2017.
Muhammad Andika Ramadhanta, Penegakan Hukum Pidana Dalam Upaya Pemberantasan Tindak Pidana Pencucian Uang Yang Berasal Dari Hasil Tindak Pidana Narkotika, Bandar Lampung: Universitas Lampung, 2016.

Naila Rizqi Zakiah, Menelusuri Perlindungan Hak Anak Pengguna Narkotika, Jurnal Peradilan Indonesia Vol. 5, Agustus 2016 - Januari 2017.

Nida Mawaddah, Perdaagangan Anak Dalam Jaringan Peredaran Narkoba Studi Kasus:Eksploitasi Anak Sebagai Kurir Narkoba di Wilayah Jakarta Barat, Skripsi, Jakarta: Universitas Islam Negeri Syarif Hidayatullah Jakarta, 2016.

Nizar Apriansyah, Peningkatan Kemampuan Petugas Pemasyarakatan dalam Menangulangi Peredaran Narkoba di Lembaga Pemasyarakatan dan Rumah Tahanan Negara, Jurnal Penelitian Hukum De Jure No:740/AU/P2MILIPI/04/2016.

Patri Handoyo, 40 Tahun "Perang Melawan Narkotika”: Pengelolaan Narkotika oleh Negara, Perang Bukan Solusi, Jurnal Peradilan Indonesia Vol. 5, Agustus 2016 - Januari 2017.

Peter Gillies (Penyunting: Barda Nawawi Arief), Criminal Law, 1990.

Qisthi Tamangpra, Pertanggungjawaban Pidana Korporasi Dalam Tindak Pidana Korupsi, Publikasi Ilmiah, Surakarta: Universitas Muhammadiyah Surakarta, 2019.

Rahmawati Silvia Riani, Penerapan Pidana Terhadap Justice Collaborator Tindak Pidana Narkotika, Jurnal Karya Ilmiah, (Lombok: Universitas Mataram, 2018).

Ridwan Arifin, Pertanggungjawaban Korporasi dalam Tindak Pidana Pencucian Uang dalam Prinsip Hukum Pidana Indonesia, Jurnal Mercatoria, 12 (1) Juni 2019.

Sakti Aminullah, Asas Strict Liability Dalam Tindak Pidana Narkotika, Jurist-Diction: Vol. 1 No. 2, November 2018. 
Jurnal Ilmiah Mandala Education

http://ejournal.mandalanursa.org/index.php/JIME/index

Terakreditasi Peringkat 4 (No. SK: 36/E/KPT/2019)

Santo Bari Gultom, Disparitas Pidana Dalam Kasus Tindak Pidana Pencucian Uang Hasil Tindak Pidana Narkotika, JOM Fakultas Hukum Volume 2 Nomor 2 Oktober 2015.

V.L. Sinta Herindrasti, Drug-free ASEAN 2025:

Tantangan Indonesia dalam

Penanggulangan Penyalahgunaan

Narkoba, Jurnal Hubungan Internasional

Vol. 7, No. 1/April - September 2018.
Vol. 6. No. 2. Oktober 2020

p-ISSN: 2442-9511 e-ISSN: 2656-5862 